Article

\title{
Uplift Evidences Related to the Recession of Groundwater Abstraction in a Pyroclastic-Alluvial Aquifer of Southern Italy
}

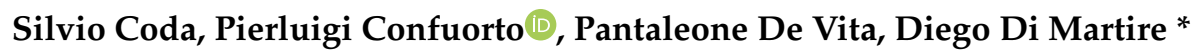 \\ and Vincenzo Allocca* \\ Department of Earth, Environmental and Resource Sciences, University of Napoli Federico II, Complesso \\ Universitario Monte S. Angelo, via Cintia, 80126 Napoli, Italy; silvio.coda@unina.it (S.C.); \\ pierluigi.confuorto@unina.it (P.C.); pantaleone.devita@unina.it (P.D.V.) \\ * Correspondence: diego.dimartire@unina.it (D.D.M.); vincenzo.allocca@unina.it (V.A.)
}

Received: 1 March 2019; Accepted: 8 May 2019; Published: 11 May 2019

check for updates

\begin{abstract}
Aquifer mismanagement is a common anthropogenic cause of subsidence and uplift phenomena in alluvial plains, representing one of the main natural hazards in urban areas due to related damage to urban structures and infrastructures. In this work, the groundwater rebound phenomenon that occurred in the last decades of the 20th century in the Lufrano area (Metropolitan area of Naples, Southern Italy) has been studied by integrating geological data, hydrogeological continuous monitoring and spaceborne SAR information derived from ERS-1/2 and ENVISAT satellites. In the period of 1989-2006, the Lufrano area, which hosts an important well field made up of 180 wells extracting groundwater for drinking use, suffered an initial over-exploitation of the aquifer which was followed by a sudden and severe decrease of the volume abstraction, resulting this last in a rapid ground uplift. The coupled analysis of hydrogeological and DInSAR data have shown a correspondence between piezometric level rise (up to $15 \mathrm{~m}$ ) and ground uplift (up to $50 \mathrm{~mm}$ ) trends in the period 1989-2006. In order to examine the spatio-temporal evolution of the phenomena and the cause-effect relationships, showing the link between the two phenomena and their rates, longitudinal cross-sections were carried out and comparisons between piezometric level rise and time-series of displacements were reconstructed. The obtained results represent an initial contribution to the definition of ground deformation related to groundwater level rise phenomena, providing a basis for future studies focused on the modelling of the hydro-mechanical properties of the aquifer.
\end{abstract}

Keywords: aquifer mismanagement; groundwater rebound; uplift; DInSAR; Italy

\section{Introduction}

The study of ground vertical deformations is particularly difficult in geologically complex areas, especially where volcano-tectonic processes are predominant, because causes of deformation are not clearly recognizable, being subject to composite temporal variabilities.

In addition to natural processes such as long-term tectonic movement [1,2], or earthquake occurrence [3,4], anthropogenic factors can contribute to ground deformation phenomena. In urban and rural areas, a common cause of vertical displacement is related to human-induced changes of water table [5]. Several studies have shown the strong correlation between groundwater abstractions and subsidence [6-8]. In particular, drastic piezometric lowering causes pore pressure decreases, leading to consolidation in cohesive deposits and compaction in incoherent ones [9].

In many cases, a drastic decrease or cessation of the withdrawal lead to a progressive recovery of piezometric levels [10]. According to the geological setting and changes in water table depth, 
surface ground deformation, both negative and positive (subsidence and uplift, respectively), can be induced. Groundwater level changes can modify the stress state of the aquifer-system materials, triggering different deformation mechanisms such as the hydrocompaction of sandy deposits, inducing subsidence phenomena $[7,11]$, or the volume increase in porous deposits, generated by the elastic recovery during the increase of pore-water pressure, whether a plastic component can couple the predominant elastic behavior [12,13]; furthermore, an increase of the pore water pressure in heavily fractured rock mass leading to uplift due to expansion of the rock matrix, may be induced [14].

Subsidence and uplift triggered by anthropogenic groundwater level fluctuations affect the structures and infrastructures, representing one of the most damaging geohazards in metropolitan areas. Therefore, monitoring and quantitative assessment of surface displacements is of paramount importance for local administrations responsible for land and risk management, being they are committed to locate and estimate the source and the amount of deformation and thus providing fundamental information to mitigate the risk. In this sense, a Remote Sensing technique, such as Spaceborne Differential Interferometry SAR (DInSAR), is a worldwide-known tool capable to provide precise information over wide areas, by overlying a stack of SAR images and generating interferograms. Such features are able to provide a deformation measurement over definite targets on the ground. DInSAR techniques have been largely implemented on large metropolitan areas such as Mexico City [15,16], Murcia [17], Rome [18], London [19-21].

One of the most common advantages of using SAR-based systems is the opportunity of having a detailed picture of the situation over wide areas and across a long time span: when available, a dataset of more than 26 years (1993-actual), covered by different satellite acquisitions, may be used to analyze a given area, with a detail not-comparable with other techniques. This may allow us to correlate short deformation periods to single man-induced events (such as fluid withdrawal or injection).

In this paper, the hydrogeological behavior of the Lufrano area (metropolitan city of Naples, southern Italy) has been investigated through an accurate reconstruction of past hydrodynamic scenarios, linked to a deformation trend reconstructed by spaceborne SAR data.

The pyroclastic-alluvial aquifer of this sector of the Campanian Plain has undergone an intense phase of over-exploitation in 1980s. Drinking water abstractions from about 180 wells of Lufrano and Acerra well fields have led to a deficit in the mean annual water budget of the aquifer [22], inducing a rapid decline of the groundwater level (up to $16 \mathrm{~m}$ ) and a deterioration of groundwater quality [23]. In 1989, this latter issue led to a partial and/or total abandonment of withdrawals followed by a groundwater recovery started in 1990 [22,24,25].

To analyze the phenomenology under consideration, piezometric levels from 1989 to 2006 and the cause-effect relationship with deformations, measured by ERS and ENVISAT data (1993-2006) have been analyzed, showing an overlap of the two phenomena in several time intervals. Since 1990, a first period, characterized by a general subsiding trend in the whole Neapolitan plain and an uplift in Lufrano area was recognized. The latter may be induced by rapid recovery of the piezometric levels, as a consequence of the groundwater exploitation drastic reduction of the pyroclastic-alluvial aquifer [22]. Following 2000, a mild deceleration of the groundwater rebound and consequently of the uplift is identified. Moreover, a geological interpretation has been given in those areas where the uplift and the piezometric rebound showed different behavior in the time-span considered.

The integration of interferometric data and piezometric levels thus provided a better definition and characterization of the hydrogeological setting and its interference on ground deformation phenomena, assisting the development of well-tailored mitigation measurements.

\section{Study Area}

The study area, extending about $40.6 \mathrm{~km}^{2}$, is located NE of the city of Naples (southern Italy) over the central sector, of the structural depression of the Campanian Plain (Figure 1), a large coastal pyroclastic-alluvial plain. Such depression, formed during the Upper Pliocene along tectonic ridges belonging to the regional tectonic extensional phase, was filled during the Quaternary by volcanic 
deposits from the intense volcanic activity of the Phlegraean Fields and Somma-Vesuvius volcanoes, started $300 \mathrm{k}-y r s$ ago [26], and by alluvial and marine sediments, in the last $25 \mathrm{k}$-yrs. The carbonate bedrock lies beneath a cover of marine, alluvial, and pyroclastic deposits, at a maximum depth of $3000 \mathrm{~m}$ [27]. It is dislocated by fault systems, mainly with extensional component [28,29]. The buried Magnaghi-Sebeto and Somma-Vesuvius faults have created locally an extensional tectonic field, as shown by the evidences in the late Pleistocene-Holocene activity [30,31] and by a gravitational sliding around the base of the Somma-Vesuvius edifice [32,33], leading to a subsiding tendency of the plain (Figure 1a).

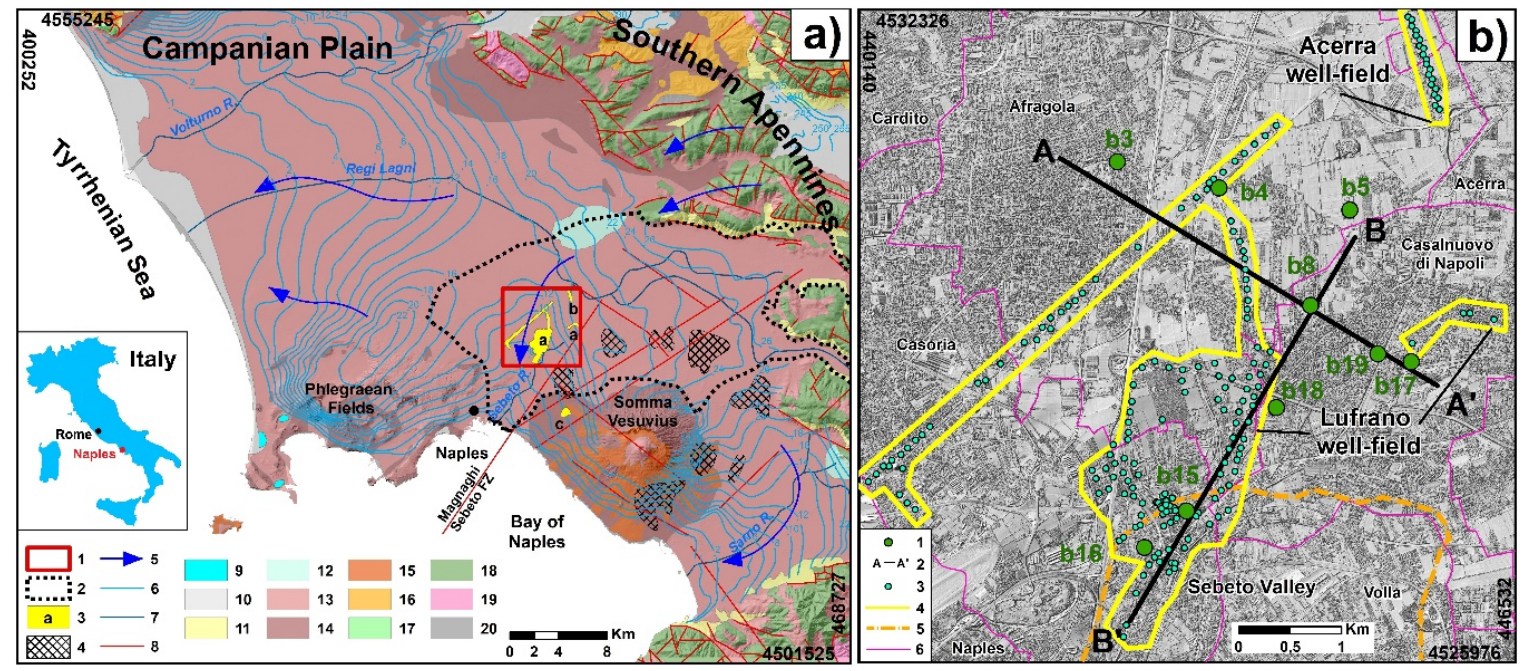

Figure 1. (a) Hydrogeological map of Campanian Plain [34]. Legend: 1) study area; 2) hydrogeological basin of eastern plain of Naples; 3) drinking-water well fields of Lufrano (a), Acerra (b), Lufrano and Ponticelli (c); 4) ring-style subsidence area [33]; 5) groundwater flow direction; 6) piezometric contour line (m a.s.l.); 7) hydrographic network; 8) normal fault; 9) lake; 10) alluvial-coastal complex; 11) epiclastic continental complex; 12) travertines complex; 13) ash-fall pyroclastic complex; 14) ash-flow pyroclastic complex; 15) volcanic rock complex; 16) arenaceous-conglomeratic complex; 17) carbonate complex of the Matese-Mount Maggiore and Mount Alpi Unit; 18) carbonate complex of the Picentino-Taburno Unit; 19) dolomite-marly complex of the Picentino-Taburno Unit; 20) clayey-calcareous complex of the Sicilian Units. (b) Lufrano and Acerra well field area. Legend: 1) borehole; 2) hydrostratigraphic section trace; 3) drinking-water well; 4) well fields area; 5) Sebeto Valley (Volla depression) northern boundary; 6) municipal boundary.

Figure 1a resumes the hydrogeological setting and groundwater flow scheme of Campania plain, elaborated by different authors [23,34,35], The central-eastern sector of Campania plain is occupied by the hydrogeological basin of the eastern plain of Naples. The study area represents a drainage zone for the groundwater of this sector, which is recharged both by the direct contributions of precipitations and by the groundwater seepage from the surrounding carbonate aquifers from NE and $\mathrm{E}$ [35]. The groundwater circulation is conditioned by the stratigraphic heterogeneity of the alluvial plain, which results in a multi-layered aquifer system (hydrostratigraphic sections, A-A' and B-B', in Figure 2). Thus, three main complexes may be recognized: a phreatic shallow aquifer hosted in the pyroclastic-alluvial deposits, a tufaceous aquitard layer, attributable to the Phlegraean eruption of the Campanian Ignimbrite (CI, dated to $39.28 \pm 0.11 \mathrm{k}-\mathrm{yrs}$; [36]) and a deep semi-confined aquifer, hosted in the coarse pyroclastic deposits pre-CI. In the southern sector, defined Sebeto Valley (Figure 1b) [27], the tufaceous horizon is absent and the aquifer is characterized by a unitary phreatic aquifer, consisting of pyroclastic, lacustrine and marine deposits. 

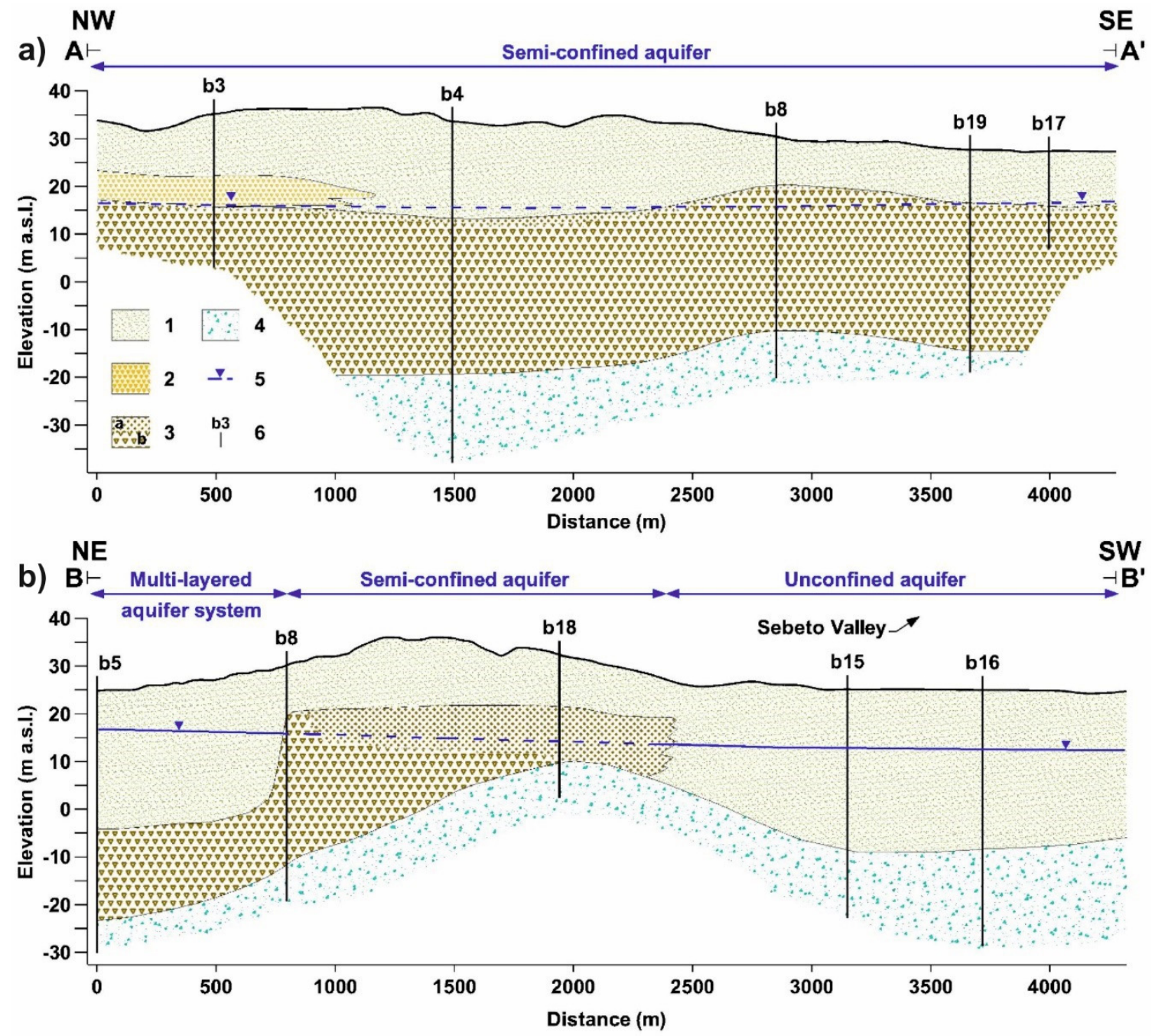

Figure 2. 2D hydrostratigraphic model of the aquifer system. Legend: 1) shallow pyroclastic-alluviallacustrine complex; 2) Neapolitan Yellow Tuff (NYT); 3) Campanian Ignimbrite (CI) in incoherent (a) or lithoid (b) facies; 4) deep pyroclastic sandy complex; 5) phreatic (a) and semi-confined (b) piezometric level; 6) borehole. See Figure $1 \mathrm{~b}$ for the location of section traces and boreholes.

After World War II, the study area of Lufrano has hosted a wells field for abstraction of drinking water from the pyroclastic-alluvial aquifer of the eastern plain of Naples. In 1989 the Acerra well field was constructed to accommodate the growing demand for water. At this time a total number of about 180 wells were in operation (Figure 1b), with pumping rates up to $4.0 \mathrm{~m}^{3} / \mathrm{s}$ (Figure 3). This generated a deficit in the mean annual water budget of the aquifer of approximately $2.65 \mathrm{~m}^{3} / \mathrm{s}$ [22].

This mismanagement of groundwater resources caused the overexploitation of the pyroclasticalluvial aquifer, with a rapid decline of the groundwater level, reaching a maximum piezometric decrease value of $16 \mathrm{~m}$ in 1989 [22]. The extraction of highly mineralized waters coming from deeper parts of the aquifer, characterized by slow circulation, has led to an increase in $\mathrm{Fe}, \mathrm{Mn}$, and fluoride concentrations (elements naturally contained in deposits of volcanic origin) $[23,34]$. The groundwater quality deterioration led to the withdrawal's drastic reduction of Lufrano well field. Therefore, starting from 1990, a continuous groundwater rebound has occurred, observed both the whole hydrogeological basin and at local scales [22,24]. In different zones of the eastern plain of Naples, environmental effects of groundwater rebound were noticed, as groundwater flooding events affecting basements, railway tunnels, agricultural lands, and archaeological sites [22,24], and ground deformation related to the increase of water pore pressure [25]. 


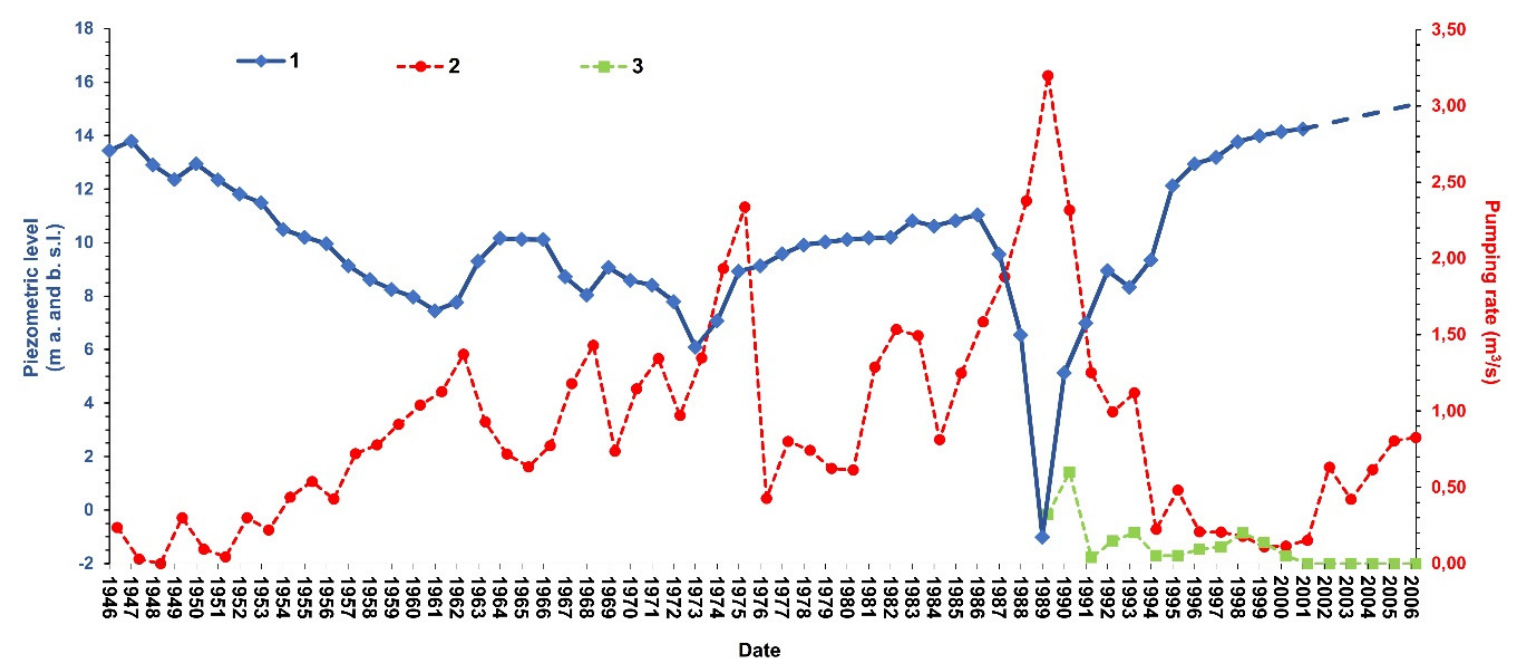

Figure 3. Piezometric level and pumping rates. 1) Lufrano well-field piezometric level; 2) pumping rate of the Lufrano well field, 3) pumping rate of the Acerra well field.

\section{Data and Methods}

\subsection{Hydrogeological Data}

Stratigraphical data of 9 boreholes (Figures $1 \mathrm{~b}$ and $4 \mathrm{a}$ ) were used to reconstruct the aquifer structure of the study area, correlating the lito-stratigraphical information to the corresponding role in the groundwater flow. Therefore, two orthogonal hydrostratigraphic cross-sections were created (A- $A^{\prime}$ and B-B' in Figure 2) to characterize the 2D structure of the aquifer. The stratigraphical dataset derives from the database of Italian Higher Institute for Environmental Protection and Research (ISPRA) [37].

To analyze the dynamics of groundwater rebound in the period 1989-2006, the spatio-temporal variations of piezometric head were reconstructed by overlapping piezometric data for 1989, 2002, and 2006. These data were collected during field surveys carried out by private companies, public agencies and researchers [34,38-40]. Piezometric contour maps were digitalized in GIS environment, (Figure $4 \mathrm{~b}-\mathrm{d}$ ) to calculate two piezometric head variation maps $(\Delta \mathrm{h}, \mathrm{m})$ for the periods 1989-2002 and 2002-2006. The piezometric contour map of 1989 (Figure 4b) shows the historical minimum groundwater levels, corresponding to the groundwater maximum over-exploitation period. In this case, values below sea level have been reached in the central sector of the Lufrano well field. In 2002-2006 maps (Figure 4c,d), an increase in piezometric head is observed as well as the depression cone absence induced by groundwater withdrawal previously detected.

Furthermore, the hydro-stratigraphic conceptual model and additional piezometric data obtained by the long-term monitoring (for the period 1985-1998, deriving by a survey of the A.M.A.N. aqueduct company) of three wells of Lufrano wells field (Figure 4a) were used to observe the possible spatial and temporal correlation between water table rise and ground deformation. 


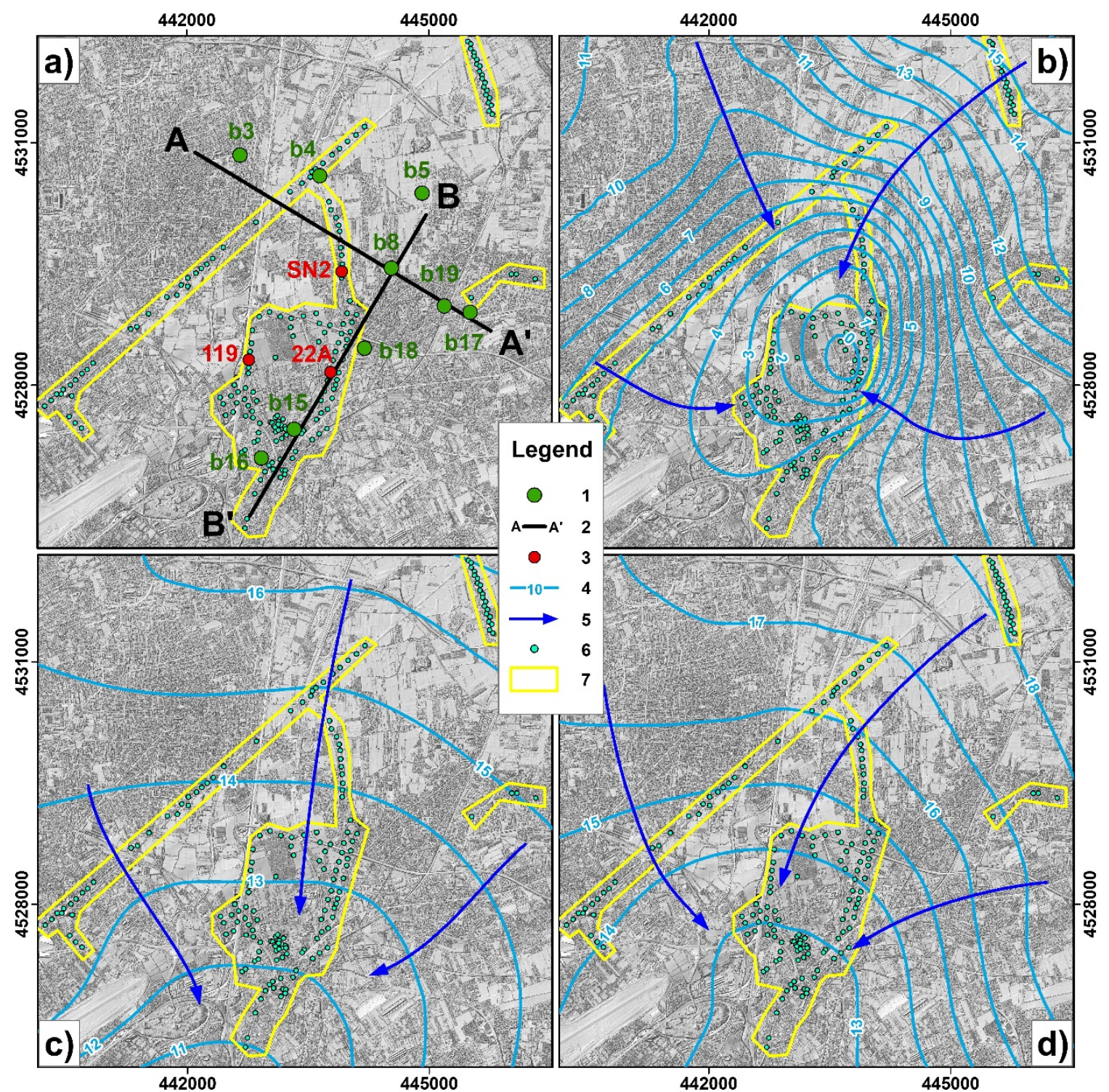

Figure 4. Location of boreholes and long-term piezometric monitoring wells (a), and groundwater flow scheme for the years: 1989 (b), 2002 (c), 2006 (d). Legend: 1) borehole; 2) trace of hydrostratigraphic cross-section; 3) long-term monitoring well; 4) water table contour (m a.s.1.); 5) groundwater flow direction; 6) drinking-water well; 7) wells field area.

\subsection{DInSAR Data}

SAR dataset belongs to the Italian First Not-Ordinary Plan of Environmental Remote Sensing project (PST-A-1 in Italian) [41,42], and it was released for scientific use in the framework of an agreement with the Italian Ministry of Environment. In detail, the PSInSAR [43] and PSP-DifSAR [44] techniques were implemented to process 139 ERS-1/2 (67 acquired over ascending orbit) and 92 ENVISAT (52 in ascending orbit) images, covering the time-span 1992-2000 and 2002-2010. In this work, only ascending data have been used. All the PSs maps contain information about velocities of displacement, coherence, cumulated displacement, and standard deviation. The assumption of the PSInSAR basic technique is the capability of identifying individual radar reflectors, the so-called permanent scatterers, which are targets that remain coherent over long time intervals, thus allowing to measure a displacement time series. A detailed description of the PS technique can be found in [43]. The basic assumption, on the other hand, of the PSP technique is that every PS is identified and analyzed only working with pairs of points called arcs; for further details about the algorithm 
interested readers can refer to [44]. In this work, PSs have been interpolated by means of Inverse Distance Weighted (IDW) algorithm.

Figure 5 shows the PS velocity maps related to the two time-span considered: in Figure 5a, ERS data highlights a general uplifting trend for the study area distributed among 7465 PSs, with highest and lowest values of displacement rate of 12.25 and $-15.44 \mathrm{~mm} / \mathrm{yr}$, respectively. In Figure $5 \mathrm{~b}$ ENVISAT data display a general stable pattern except for subsidence phenomena registered in the SE and SW areas. Here, highest and lowest values of deformation rates are, among the 7816 PSs, 5.4 and $-16.2 \mathrm{~mm} / \mathrm{yr}$. Stability ranges of the two PSs velocity maps have been calculated multiplying 1.5 times the standard deviation of stable points, which is, for ERS and ENVISAT data, 0.62 and 0.65 , respectively. In Table 1 , the PSs main figures are resumed.

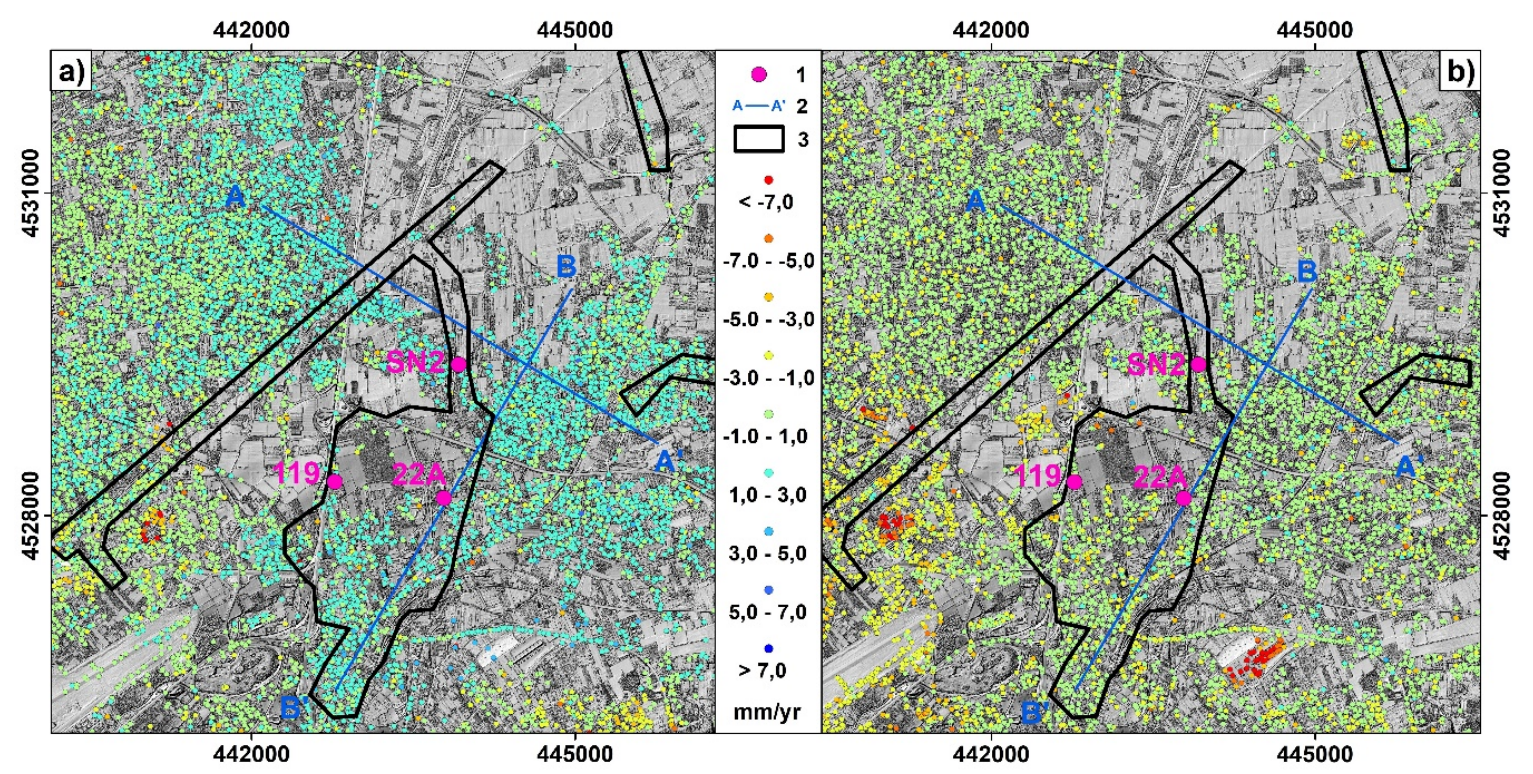

Figure 5. Line of Sight (LoS) velocity maps (mm/yr) of the study area by ERS1/2 (a) and ENVISAT (b) data. Legend: 1) long-term monitoring well; 2) trace of hydrostratigraphic cross-section; 3) wells field area.

Table 1. Differential Interferometry SAR (DInSAR) LoS measurement statistics referred to the whole area.

\begin{tabular}{ccc}
\hline Displacement Rate & $\begin{array}{c}\text { ERS1/2 } \\
\mathbf{1 9 9 3 - 2 0 0 0}\end{array}$ & $\begin{array}{c}\text { ENVISAT } \\
\text { 2002-2006 }\end{array}$ \\
\hline Highest value & $12.25 \mathrm{~mm} / \mathrm{yr}$ & $5.40 \mathrm{~mm} / \mathrm{yr}$ \\
\hline Lowest value & $-15.44 \mathrm{~mm} / \mathrm{yr}$ & $-16.20 \mathrm{~mm} / \mathrm{yr}$ \\
\hline Mean value & $0.87 \mathrm{~mm} / \mathrm{yr}$ & $-0.62 \mathrm{~mm} / \mathrm{yr}$ \\
\hline Standard deviation & 0.62 & 0.65 \\
\hline PS density & $183.8 \mathrm{PSs} / \mathrm{km}^{2}$ & $192.5 \mathrm{PSs} / \mathrm{km}^{2}$ \\
\hline
\end{tabular}

\section{Results}

\subsection{Piezometric Head Variation Maps}

The groundwater recovery is clearly recognizable in the piezometric head variation maps (Figure 6a,b). A significant rise, in the period of 1989-2002, with values up to 13 meters in the central sector of the study area may be recognized (Figure 6a). In the same sector, during the following five years (2002-2006), the groundwater recovery continued with a slower trend and with values between few centimeters and 3 meters (Figure $6 \mathrm{~b}$ ). The maximum groundwater recovery, for the whole period considered, is of $15 \mathrm{~m}$, thus reaching values of piezometric head height similar to 1946 (see 
Figure 3). The calculated piezometric rising values are consistent with previous studies carried out in the surrounding areas [25]. Those works also showed that the rise is not induced by an increase in the precipitation regime but rather by the drastic reduction of the groundwater abstraction.

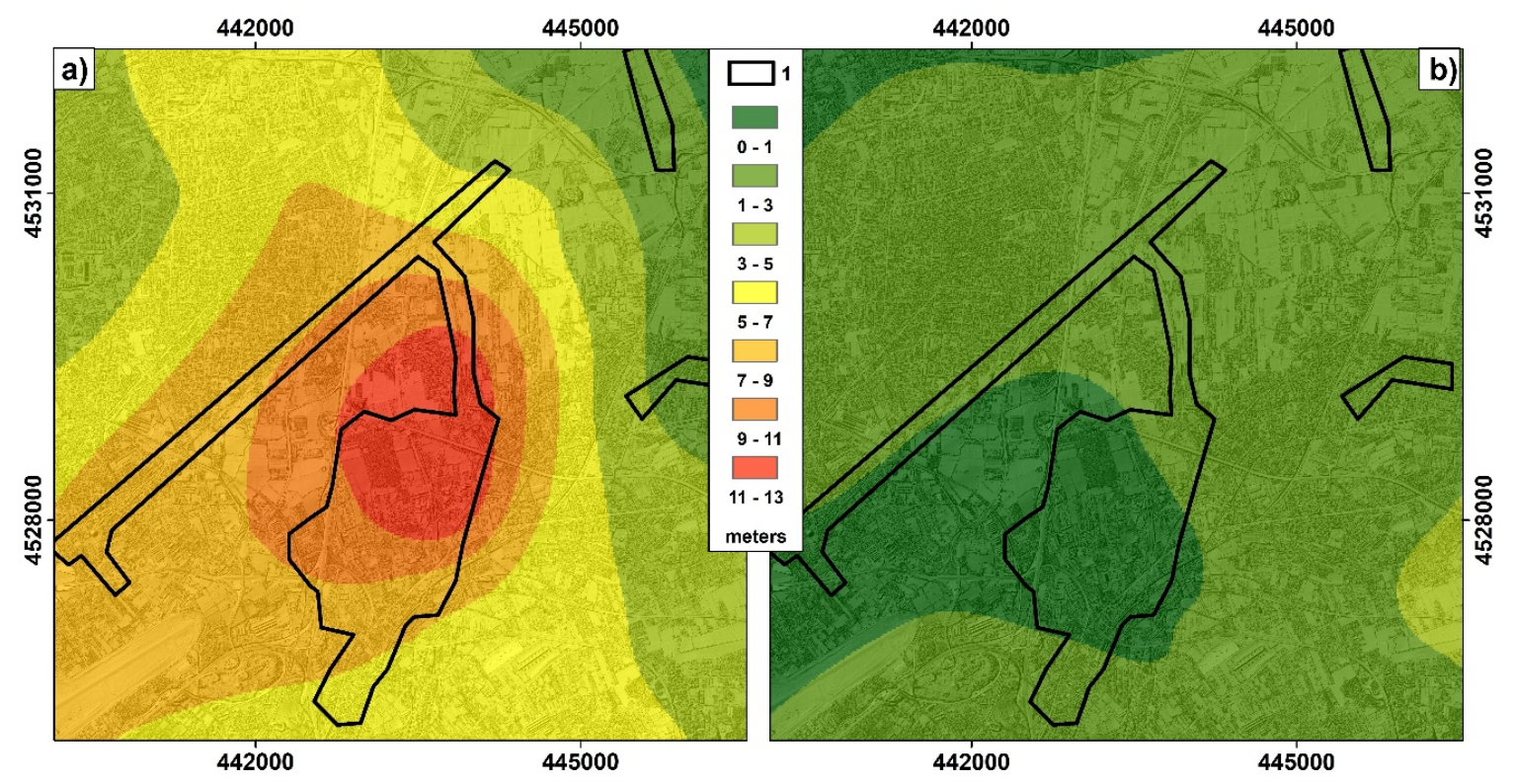

Figure 6. Piezometric level variation (m) in the period 1989-2002 (a) and 2002-2006 (b). Legend: 1) wells field area. The piezometric variation values were classified using a constant interval of $2 \mathrm{~m}$.

\subsection{Satellite-Based Deformation Maps}

Two different cumulative displacement maps were elaborated, starting from the ERS-1/2 and ENVISAT data, for the timespans 1993-2000 and 2002-2006, respectively. The interpolation has been carried out by means of IDW algorithm, obtaining a continuous map of $50 \mathrm{~m}$-cell resolution. Such value has been chosen according to the ERS and ENVISAT resolution $(20 \times 4 \mathrm{~m})$ and to the PS density of the area. The interpolation process enables the examination of the whole area of interest, measuring values surrounding the prediction location for any unmeasured location. Hence, the interpolation has permitted the generation of spatial profiles of deformation, providing precise information on displacement rates in different areas. The 1993-2000 ERS1/2 data map (Figure 7a) shows a general uplifting deformation pattern in Lufrano area, with maximum values of displacement of $38 \mathrm{~mm}$ in the time-span considered (Table 2). Moreover, more than 20 PSs have displacement value higher than $20 \mathrm{~mm}$ and about 270 PSs are characterized by displacement higher than $10 \mathrm{~mm}$. Their distribution is mostly concentrated in the Lufrano area, in the inhabited area adjacent to the wells field. It is also worth pointing out that a subsiding trend in the area located SE of the Lufrano area, falling within the ring-style subsidence areas (see Figure 1a) [33], with values of displacement ranging from -20 to $-60 \mathrm{~mm}$ for about 100 PSs. Other subsiding bowls are located in the western sector of the study area, with values of deformation up to $-50 \mathrm{~mm}$. 


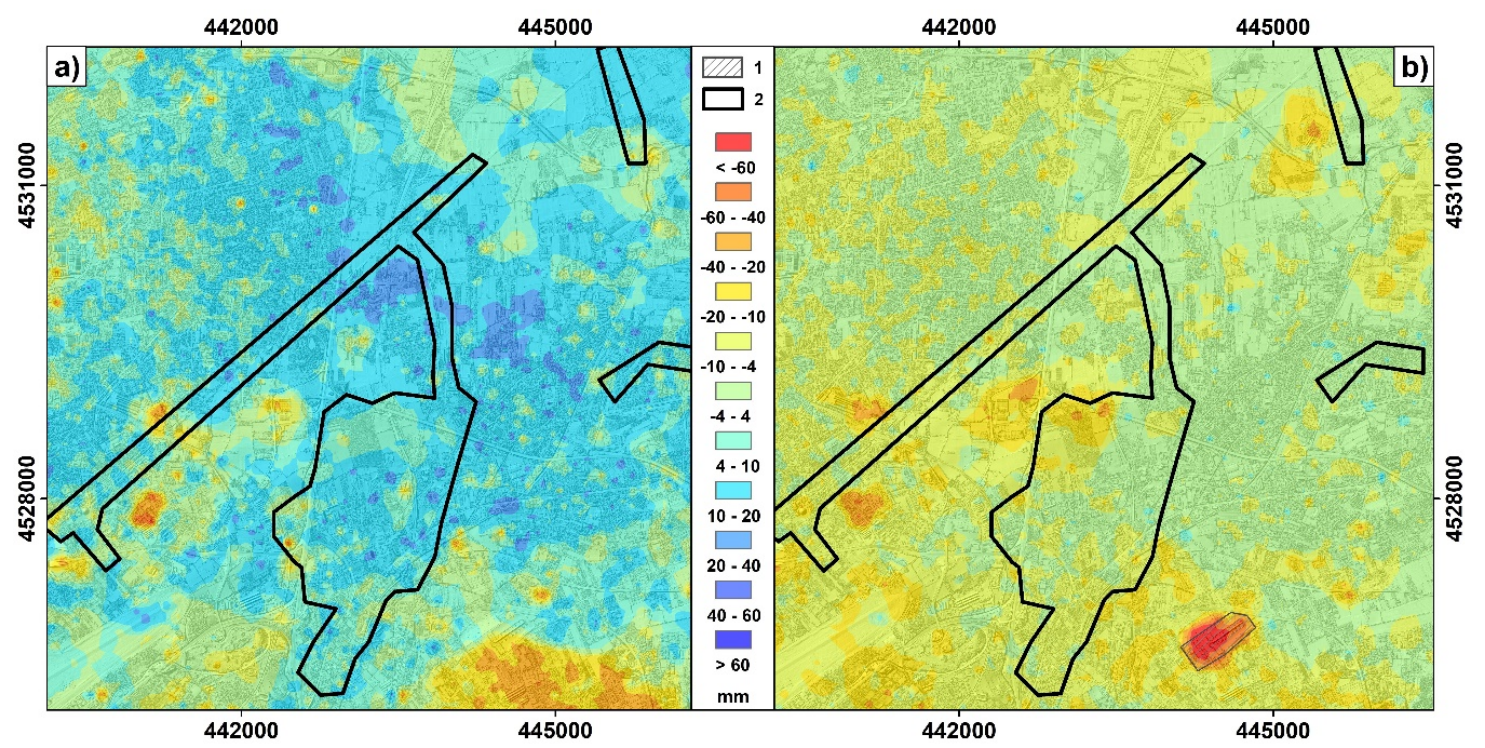

Figure 7. DInSAR-derived displacement maps: a) ERS-1/2, 1992-2000 period; b) ENVISAT, 2002-2006 period. Legend: 1) Agrifood Centre of Naples (CAAN); 2) wells field area.

Table 2. DInSAR LoS measurements referred to the whole area.

\begin{tabular}{ccc}
\hline Vertical Displacement & $\begin{array}{c}\text { ERS1/2 } \\
\text { 1993-2000 }\end{array}$ & $\begin{array}{c}\text { ENVISAT } \\
\mathbf{2 0 0 2 - 2 0 0 6}\end{array}$ \\
\hline Highest displacement & $63.60 \mathrm{~mm}$ & $19.81 \mathrm{~mm}$ \\
\hline Lowest displacement & $-73.58 \mathrm{~mm}$ & $-95.39 \mathrm{~mm}$ \\
\hline Mean displacement & $7.94 \mathrm{~mm}$ & $-5.11 \mathrm{~mm}$ \\
\hline Standard deviation & 2.7 & 2.6 \\
\hline
\end{tabular}

ENVISAT data ranging from 2000 to 2006 (Figure 7b) also shows both uplifting and subsiding trends However, the distribution of PSs showing uplift is slightly different from the previous dataset: the area of Lufrano, indeed, shows a generally reduced trend of uplift, with many PSs characterized by lower values of deformation, with average values of about $10 \mathrm{~mm}$ at the last time period considered (2006). On the other hand, the subsiding trend in the SE area shows a general slowdown, unless some PSs showing values of deformation up to $-100 \mathrm{~mm}$ all distributed over the Agrifood Centre of Napoli (CAAN) of Volla town. Such deformation can be related to the consolidation of the terrain after the beginning of the building, completed in 2008, extending for more than $350.000 \mathrm{~m}^{2}$. The western sector of the study area also confirms a subsiding trend, over the same areas identified in the previous dataset.

\section{Discussion}

In this work, a coupled analysis of hydrogeological and interferometric data was carried out in order to find a cause-effect relationship between the rise of piezometric levels and the ground uplift.

The spatial comparison between the piezometric and ground deformation profiles, calculated along the cross-sections A-A' and B-B' (Figure 8), shows that the deformation behavior depends on the local structure of the aquifer. In detail, along the A-A' cross-section (Figure 8a), in the periods 1989-2002 (referred to piezometric data) and 19932000 (referred to interferometric data) an average piezometric rise of about 7.7 meters and an average uplift of $14.4 \mathrm{~mm}$ was recorded. In the period of 2002-2006, the groundwater rebound was lower $(1.6 \mathrm{~m})$, and no appreciable soil deformation was detected, being this trend generally recognizable throughout the whole study area, as shown in Figure 6; Figure 7. For the entire cross-section, the piezometric changes concern the deep semi-confined aquifer leading to an increment of the potential head rather than a rise of the water table. The homogeneity of the aquifer system influences the deformation profile pattern, which shows up slightly rough. 
Along the B-B' cross-section, for the stretch characterized by a multi-layered aquifer system, the piezometric rise affected the shallow phreatic aquifer (Figure 8b), with values of about $8 \mathrm{~m}$ (first period) and $5 \mathrm{~m}$ (second period), and a maximum value of average vertical displacement of about 16 $\mathrm{mm}$ was recorded. The sector characterized by a strong heterogeneity in the aquifer's structure shows the greater spatial irregularity of the vertical displacement (Figure 8c); the piezometric rise (up to $16 \mathrm{~m}$ in the entire period) has involved the deep aquifer, in the first period in phreatic condition and then partially semi-confined with the tufaceous aquitard in incoherent facies. The last sector (Figure 8d) is characterized by an unconfined aquifer, in which a piezometric rise of about $5 \mathrm{~m}$ (in the first period) correspond to an average uplift of about $10 \mathrm{~mm}$.

Therefore, the integrated monitoring and analysis of piezometric rise and deformation highlighted the different behavior of different sectors of the plain, being characterized by extremely heterogeneous structures. The shallow phreatic aquifer of the NE multi-layered system showed the highest displacement values (Figure $8 \mathrm{~b}$ ), while the unconfined aquifer of the $\mathrm{S}$ sector the lowest values (Figure 8d). The strongly heterogeneous sector in the central sector is characterized by an irregular displacement pattern (Figure 8c).

The radius of influence of the wells field during the recovery period has been also analyzed, by plotting together piezometric head variations and displacement rates (Figure 9). Piezometric head variations have been compared with ERS data, for the first period (see Figures 5a and 6a), along four profiles, starting from the maximum piezometric rise area and towards the NW, NE, SW, and SE directions. Such a comparison shows a very similar decreasing trend in all four directions, both for displacement and for piezometric change entities. Higher displacement rates can be found in proximity of the area interested by the maximum piezometric recovery, while they decrease moving away from this sector. This further analysis confirms the relationship between recovery of the piezometric level and vertical displacements, showing how the distance from the wells field influences surface deformation.

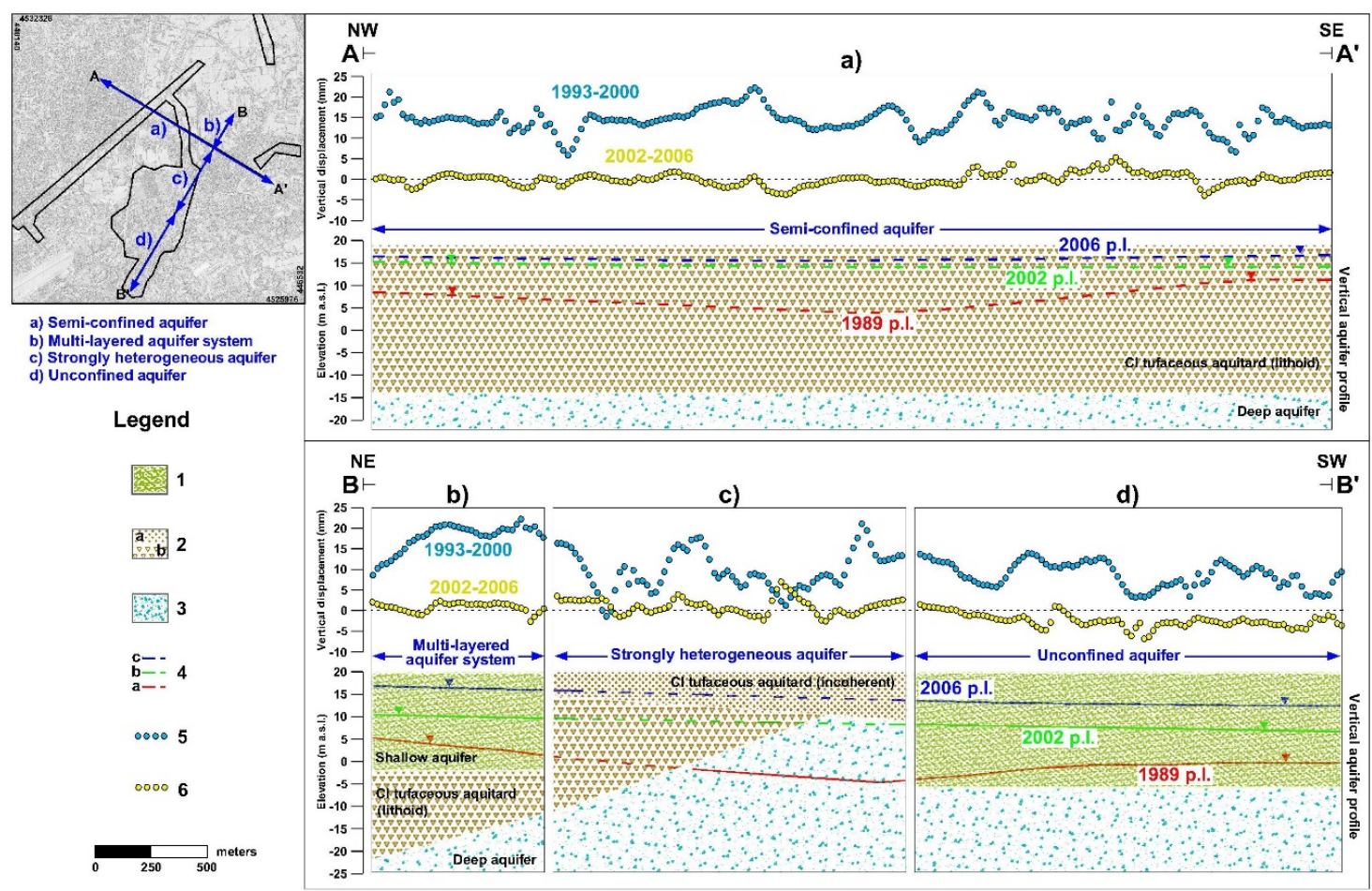

Figure 8. Groundwater levels and ground vertical deformations along the section traces A-A' (a) and B-B' (b-d). Legend: 1) shallow pyroclastic-alluvial-lacustrine complex; 2) Campanian Ignimbrite (CI) in incoherent (a) or lithoid (b) facies; 3 ) the deep pyroclastic sandy complex; 4) piezometric level (m a.s.l.) for the years 1989 (a), 2002 (b) and 2006 (c); 5) vertical displacement (mm) in the period 1993-2000; 6) vertical displacement $(\mathrm{mm})$ in the period 2002-2006. 

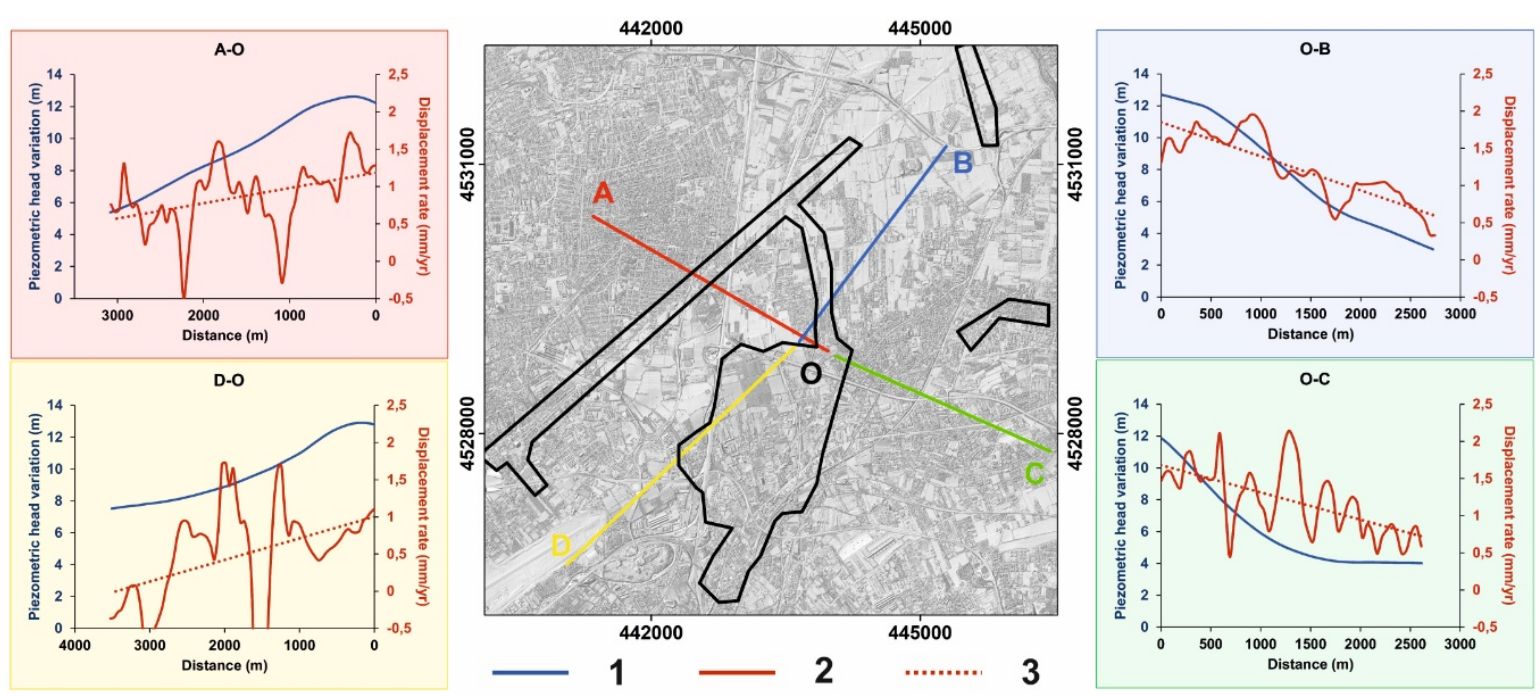

Figure 9. Scheme of the radius of influence of Lufrano wells field during the recovery period. In the middle, study area with profile traces. On both sides, ERS displacement rates (period 1992-2000, see Figure 5a) vs. piezometric head variation (period 1989-2002, see Figure 6a) along the section traces. Legend: 1) piezometric head variation profile; 2 ) displacement rate profile; 3 ) trend of displacement rate profile.

The correlation between the piezometric level rise and the vertical displacement can be observed not only along spatial profiles, but also over the whole analysis period, by interpreting the time-series related to three wells of Lufrano wells field (Figure 10). Comparing the deformation data to the piezometric data, the strong correlation between the trends can be observed. Two different phases are recognizable (Figure 10a,b): a first one (until 1997) is characterized by a piezometric rising rate of about $1.5 \mathrm{~m} / \mathrm{yr}$ and $1.3 \mathrm{~m} / \mathrm{yr}$, and an average displacement rate of about $2.5 \mathrm{~mm} / \mathrm{yr}$ and $3.2 \mathrm{~mm} / \mathrm{yr}$ for the wells 22A and 119 respectively, followed by a second phase characterized by a stable trend both for piezometric and for displacement data. Nevertheless, in the well sn2 (Figure 10c), ground deformations show a non-linear trend, being characterized by average displacement rate of $1.5 \mathrm{~mm} / \mathrm{yr}$ in the first period and by a stable trend in the second one. Conversely the rate of piezometric rise is constant for both periods $(1.2 \mathrm{~m} / \mathrm{yr})$.

It must be stated also that, in a general uplifting trend of the Lufrano area, some subsiding areas are recognized in the two investigation periods. On one hand, the subsiding area of the SE sector mightbe reconducted to the volcano-tectonics dynamics of Somma-Vesuvius complex, as documented by [33], which is characterized by a peculiar annular shape, along the northern footslope of the volcano. Such phenomenon is more evident in the 1992-2000 period, being characterized by higher deformation, with respect to the following time-span (2002-2006). Furthermore, the values of ERS displacement rates and cumulative deformation of this work are in agreement with those calculated by [33]: the average PS velocity of such a sector is -0.4 while the cumulative deformation average is $52 \mathrm{~mm}$, and is thus consistent with the ranges of [33].

On the other hand, the area where the CAAN was constructed most likely suffered local settlements phenomena and consolidation of the terrains during the building period. This trend can be observed only in the ENVISAT analysis. 

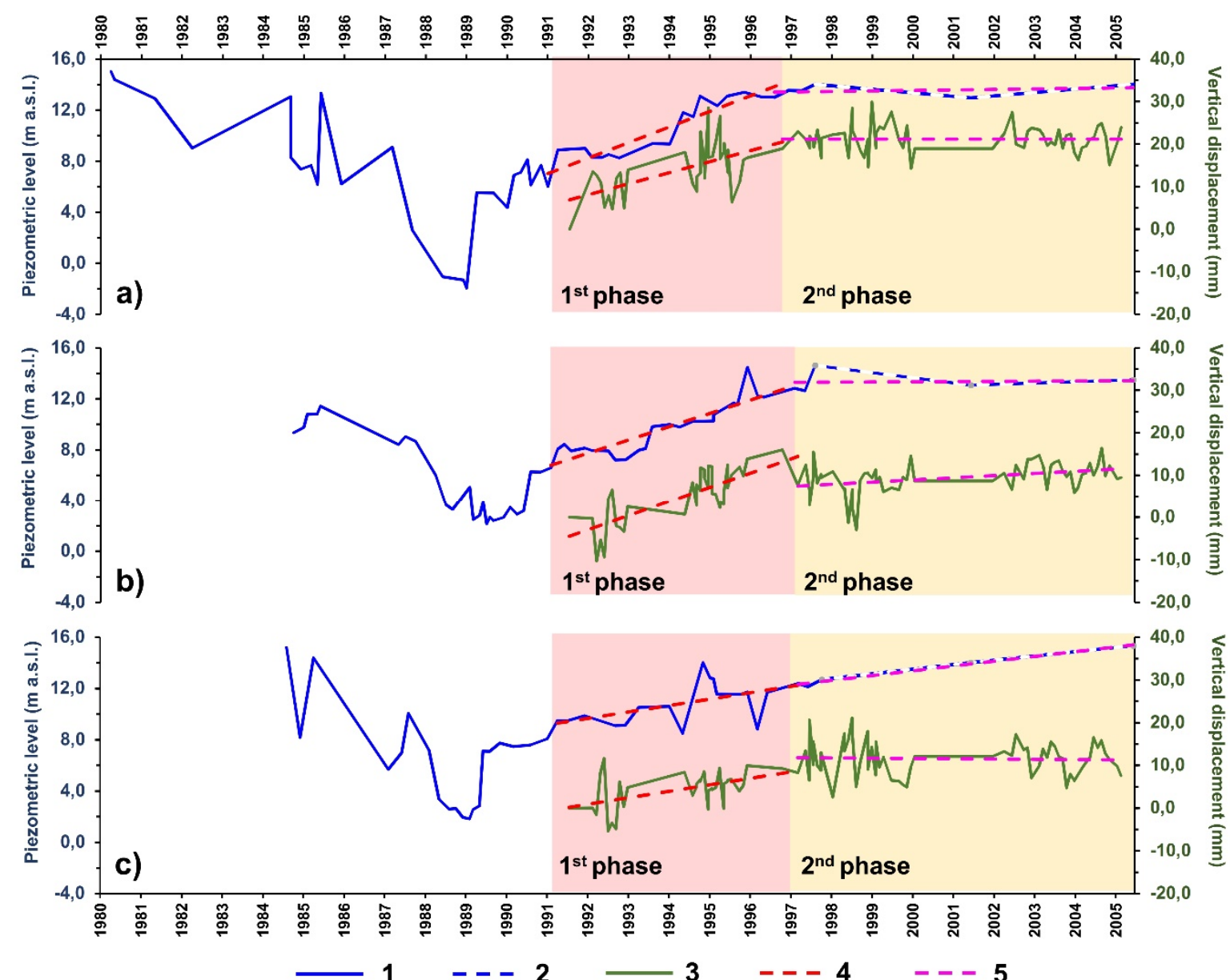

Figure 10. Piezometric levels and vertical displacement of the wells $22 \mathrm{~A}(\mathbf{a}), 119$ (b) and sn2 (c). Legend: 1) piezometric level (m a.s.l.); piezometric level interpolated (see Figure 3c,d) (m a.s.l.); 3) vertical displacement $(\mathrm{mm}) ; 4)$ trends in the first phase; 5) trends in the second phase.

\section{Conclusions}

Aquifer mismanagement has always been a main triggering cause for ground deformation, as testified by numerous authors [5-9,21,25], with different mechanisms according to the type of aquifer involved. In this work, a pyroclastic-alluvial aquifer was investigated, analyzing the cause-effect relationship between groundwater level rise and ground deformation. The Lufrano area is characterized by a well field intensely overexploited in the 70-80s. Because of water quality deterioration, a sudden reduction of the groundwater pumped volumes occurred, causing the so-called rebound of the piezometric level. Such an event had consequences on the ground, causing a significant uplift phenomenon, which was detected by the SAR satellites, such as ERS-1/2 and ENVISAT, in the period 1993-2006. The spatio-temporal evolution of ground deformation, covering the period of 1993-2006, was analyzed by means of DInSAR data, linking this phenomenon to the significant reduction of groundwater pumping, started 1989, as observed by hydrogeological data.

Hydrogeological monitoring data show, for the 1989-2006 period, that groundwater level rise was widespread throughout the study area, with a maximum amplitude of $14 \mathrm{~m}$ in the central sector and a piezometric rising rate up to $1.5 \mathrm{~m} / \mathrm{yr}$. During the time span of 1993-2006, DInSAR data show general ground uplift, even though characterized by a non-linear trend with a magnitude up to $50 \mathrm{~mm}$ following a piezometric rising rate up to $1.5 \mathrm{~m} / \mathrm{yr}$. Moreover, the radial influence of the study area has been analyzed, showing how the deformation is mainly located in the range of Lufrano well field. Temporal comparisons between groundwater levels and ground displacement trends indicate that the 
land uplift may be due to poro-elastic rebound mechanism [12,13] in the multi-layered aquifer system, triggered by piezometric level rise following the groundwater pumping interruption.

Obtained results increase knowledge on the effects induced by groundwater rebound affecting the study area, characterized by a high fluvial and groundwater flooding susceptibility. Therefore, to a consistent analysis of complex and interactive phenomena, such as those observed in the study area, where groundwater rebound, ground uplift, and groundwater flooding coexist, the implementation of appropriate hydrogeological and hydro-mechanical models and groundwater flooding susceptibility assessment methods are needed for a correct management of different hydrogeological risks.

Author Contributions: Conceptualization, V.A. and S.C.; methodology, S.C., P.C., and D.D.M.; validation, S.C., D.D.M.; writing—original draft preparation, S.C. and P.C.; writing-review and editing, V.A.; supervision, P.D.V.

Funding: This research received no external funding.

Acknowledgments: PS data (ERS and ENVISAT) were provided by the Italian Ministry of Environment, Territory and Sea (MATTM).

Conflicts of Interest: The authors declare no conflict of interest.

\section{References}

1. Chen, Y.G.; Liu, T.K. Holocene uplift and subsidence along an active tectonic margin southwestern Taiwan. Quat. Sci. Rev. 2000, 19, 923-930. [CrossRef]

2. Perrone, G.; Morelli, M.; Piana, F.; Fioraso, G.; Nicolò, G.; Mallen, L.; Cadoppi, P.; Balestro, G.; Tallone, S. Current tectonic activity and differential uplift along the Cottian Alps/Po Plain boundary (NW Italy) as derived by PS-InSAR data. J. Geodyn. 2013, 66, 65-78. [CrossRef]

3. Meltzner, A.J.; Sieh, K.; Abrams, M.; Agnew, D.C.; Hudnut, K.W.; Avouac, J.P.; Natawidjaja, D.H. Uplift and subsidence associated with the great Aceh-Andaman earthquake of 2004. J. Geophys. Res. Solid Earth 2006, 111. [CrossRef]

4. Chini, M.; Bignami, C.; Stramondo, S.; Pierdicca, N. Uplift and subsidence due to the 26 December 2004 Indonesian earthquake detected by SAR data. Int. J. Remote Sens. 2008, 29, 3891-3910. [CrossRef]

5. Galloway, D.L.; Jones, D.R.; Ingebritsen, S.E. Land Subsidence in the United States; US Geological Survey: Reston, VA, USA, 1999.

6. González-Morán, T.; Rodrıguez, R.; Cortes, S.A. The Basin of Mexico and its metropolitan area: Water abstraction and related environmental problems. J. S. Am. Earth Sci. 1999, 12, 607-613. [CrossRef]

7. Amin, A.; Bankher, K. Causes of land subsidence in the Kingdom of Saudi Arabia. Nat. Hazards 1997, 16, 57-63. [CrossRef]

8. Carminati, E.; Martinelli, G. Subsidence rates in the Po Plain, northern Italy: The relative impact of natural and anthropogenic causation. Eng. Geol. 2002, 66, 241-255. [CrossRef]

9. Lofgren, B.E.; Klausing, R.L. Land Subsidence Due to Ground-Water Withdrawal, Tulare-Wasco Area, California; US Government Printing Office: Washington, DC, USA, 1969.

10. Wilkinson, W.B. Groundwater Problems in Urban Areas; Tomas Telford: London, UK, 1994.

11. Terranova, C.; Ventura, G.; Vilardo, G. Multiple causes of ground deformation in the Napoli metropolitan area (Italy) from integrated Persistent Scatterers DinSAR, geological, hydrological, and urban infrastructure data. Earth Sci. Rev. 2015, 146, 105-119. [CrossRef]

12. Biot, M.A. General theory of three dimensional consolidation. J. Appl. Phys. 1941, 12, 155-164. [CrossRef]

13. Allen, D.R.; Mayuga, M.N. The mechanics of compaction and rebound, Wilmington Oil Field, Long Beach, California, U.S.A. In Proceedings of the Tokyo Symposium on Land Subsidence 2; International Association of Scientific Hydrology and UNESCO, Tokyo, Japan, 17-24 September 1969; pp. 410-423.

14. Donnelly, L.J. A review of international cases of fault reactivation during mining, subsidence and fluid abstraction. Q. J. Eng. Geol. Hydrog. 2009, 42, 73-94. [CrossRef]

15. Strozzi, T.; Wegmuller, U. Land subsidence in Mexico City mapped by ERS differential SAR interferometry. In Proceedings of the IEEE 1999 International Geoscience and Remote Sensing Symposium IGARSS'99 (Cat. No. 99CH36293), Hamburg, Germany, 28 June-2 July 1999; Volume 4, pp. 1940-1942.

16. Osmanoğlu, B.; Dixon, T.H.; Wdowinski, S.; Cabral-Cano, E.; Jiang, Y. Mexico City subsidence observed with persistent scatterer InSAR. Int. J. Appl. Earth Obs. 2011, 13, 1-12. [CrossRef] 
17. Tomás, R.; Herrera, G.; Delgado, J.; Lopez-Sanchez, J.M.; Mallorquí, J.J.; Mulas, J. A ground subsidence study based on DInSAR data: Calibration of soil parameters and subsidence prediction in Murcia City (Spain). Eng. Geol. 2010, 111, 19-30. [CrossRef]

18. Zeni, G.; Bonano, M.; Casu, F.; Manunta, M.; Manzo, M.; Marsella, M.; Pepe, A.; Lanari, R. Long-term deformation analysis of historical buildings through the advanced SBAS-DInSAR technique: The case study of the city of Rome, Italy. J. Geophys. Eng. 2011, 8, S1-S12. [CrossRef]

19. Milillo, P.; Giardina, G.; DeJong, M.; Perissin, D.; Milillo, G. Multi-temporal InSAR structural damage assessment: The London crossrail case study. Remote Sens. 2018, 10, 287. [CrossRef]

20. Bonì, R.; Cigna, F.; Bricker, S.; Meisina, C.; McCormack, H. Characterisation of hydraulic head changes and aquifer properties in the London Basin using Persistent Scatterer Interferometry ground motion data. J. Hydrol. 2016, 540, 835-849. [CrossRef]

21. Bonì, R.; Bosino, A.; Meisina, C.; Novellino, A.; Bateson, L.; McCormack, H. A methodology to detect and characterize uplift phenomena in urban areas using Sentinel-1 data. Remote Sens. 2018, 10, 607. [CrossRef]

22. Allocca, V.; Celico, P. Hydrodynamics scenarios in the eastern plain of Naples (Italy), in the last century: Causes and hydrogeological implications. G. Geol. Appl. 2008, 9, 175-198.

23. Celico, P.; Esposito, L.; de Gennaro, M.; Mastrangelo, E. La falda ad Oriente della città di Napoli: Idrodinamica e qualità delle acque. Geol. Romana 1994, 30, 653-660.

24. Allocca, V.; Coda, S.; De Vita, P.; Iorio, A.; Viola, R. Rising groundwater levels and impacts in urban and semirural areas around Naples (southern Italy). Rend. Online Soc. Geol. It. 2016, 41, 14-17.

25. Coda, S.; Tessitore, S.; Di Martire, D.; Calcaterra, D.; De Vita, P.; Allocca, V. Coupled ground uplift and groundwater rebound in the metropolitan city of Naples (southern Italy). J. Hydrol. 2019, 569, 470-482. [CrossRef]

26. Rolandi, G.; Bellucci, F.; Heizler, M.T.; Belkin, H.E.; De Vivo, B. Tectonic controls on the genesis of ignimbrites from the Campanian volcanic zone, southern Italy. Miner. Petrol. 2003, 79, 3-31. [CrossRef]

27. Bellucci, F. Nuove conoscenze stratigrafiche sui depositi vulcanici del sottosuolo del settore meridionale della Piana Campana. Boll. Soc. Geol. It. 1994, 113, 395-420.

28. Ortolani, F.; Aprile, F. Principali caratteristiche stratigrafiche e strutturali dei depositi superficiali della Piana Campana. Boll. Soc. Geol. It. 1985, 104, 195-206.

29. Costanzo, M.R.; Nunziata, C. Lithospheric vs. models in the Campanian Plain (Italy) by integrating Rayleigh wave dispersion data from noise cross-correlation functions and earthquake recordings. Phys. Earth Planet. Inter. 2014, 234, 45-59. [CrossRef]

30. Cinque, A.; Ascione, A.; Caiazzo, C. Distribuzione spazio-temporale e caratterizzazione della fogliazione quaternaria in Appennino meridionale. In Le Ricerche del GNDT nel Campo della Pericolosità Sismica; Galadini, F., Meletti, C., Rebez, A., Eds.; CNR—Gruppo Nazionale per la Difesa dai Terremoti: Rome, Italy, 2000; pp. 203-218.

31. Santangelo, N.; Romano, P.; Ascione, A.; Ermolli, E.R. Quaternary evolution of the Southern Apennines coastal plains: A review. Geol. Carpath. 2017, 68, 43-56. [CrossRef]

32. Bianco, F.; Castellano, M.; Milano, G.; Ventura, G.; Vilardo, G. The Somma-Vesuvius stress field induced by regional tectonics: Evidences from seismological and mesostructural data. J. Volcanol. Geoth. Res. 1998, 82, 199-218. [CrossRef]

33. Lanari, R.; De Natale, G.; Berardino, P.; Sansosti, E.; Ricciardi, G.P.; Borgstrom, S.; Capuano, P.; Pingue, P.; Troise, C. Evidence for a peculiar style of ground deformation inferred at Vesuvius volcano. Geophys. Res. Lett. 2002, 29, 1292. [CrossRef]

34. De Vita, P.; Allocca, V.; Celico, F.; Fabbrocino, S.; Mattia, C.; Monacelli, G.; Musilli, I.; Piscopo, V.; Scalise, A.R.; Summa, G.; et al. Hydrogeology of continental southern Italy. J. Maps 2018, 14, 230-241.

35. Esposito, L. Nuove conoscenze sulle caratteristiche idrogeochimiche della falda ad Oriente della città di Napoli (Campania). Q. Geol. Appl. 1998, 5.

36. De Vivo, B.; Rolandi, G.; Gans, P.B.; Calvert, A.; Bohrson, W.A.; Spera, F.J.; Belkin, A.E. New constraints on the pyroclastic eruption history of the Campanian volcanic plain (Italy). Miner. Petrol. 2001, 73, 47-65. [CrossRef]

37. Geological Survey of Italy (SGI) Database. Available online: http://www.isprambiente.gov.it/en/databases/ soil-and-territory (accessed on 1 March 2019). 
38. Celico, P.; de Paola, P. La falda dell'area napoletana: Ipotesi sui meccanismi naturali di protezione e sulle modalità di inquinamento. In Atti Giornata di Studio "Acque per Uso Potabile"; CI ESSE I Centro Scientifico Internazionale: Milan, Italy, 1992; pp. 387C-412C.

39. Autorità di Bacino Regionale Nord Occidentale della Campania. Il Contributo al Piano di Tutela delle Acque della Regione Campania; Grafica Montese snc: Naples, Italy, 2004; Volume I-III.

40. Dati, F. Emungimenti e Subsidenza nell'Area Nord-Orientale di Napoli. Master's Thesis, Università degli Studi di Napoli Federico II, Naples, Italy, 2006.

41. Costabile, S. The national geoportal: The not-ordinary plan of environmental remote sensing. GEOmedia 2010, 14, 3. (In Italian)

42. Di Martire, D.; Paci, M.; Confuorto, P.; Costabile, S.; Guastaferro, F.; Verta, A.; Calcaterra, D. A nation-wide system for landslide mapping and risk management in Italy: The second Not-ordinary Plan of Environmental Remote Sensing. Int. J. Appl. Earth Obs. 2017, 63, 143-157. [CrossRef]

43. Ferretti, A.; Prati, C.; Rocca, F. Permanent scatterers in SAR interferometry. IEEE Trans. Geosci. Remote 2001, 39, 8-20. [CrossRef]

44. Costantini, M.; Falco, S.; Malvarosa, F.; Minati, F. A new method for identification and analysis of persistent scatterers in series of SAR images. In Proceedings of the IGARSS 2008-2008 IEEE International Geoscience and Remote Sensing Symposium, IEEE, Boston, MA, USA, 6-11 July 2008; Volume 2, pp. 2-449.

(C) 2019 by the authors. Licensee MDPI, Basel, Switzerland. This article is an open access article distributed under the terms and conditions of the Creative Commons Attribution (CC BY) license (http://creativecommons.org/licenses/by/4.0/). 